\title{
The Application of GIS and Remote Sensing for Evaluating Land use/Land Cover Dynamics in Megech Watershed, Upper Blue Nile Basin Ethiopia
}

\author{
Zemenu Awoke $^{1}$ Adugaw Brihanu ${ }^{2}$ Tesfahu Fentahu ${ }^{3}$ Dr. Daniel Ayalew ${ }^{4,5}$ \\ 1. Gambella University College of Agriculture and Natural Resource, Ethiopia \\ 2. Debre Tabor University College of Agriculture and Natural Resource, Ethiopia \\ 3.Debre Markos University College of Agriculture and Natural Resource, Ethiopia \\ 4.Bahir Dar University Department of Geography and Environmental Studies, Ethiopia \\ 5. Director of Geospatial Data and Technology Center, Bahir Dar University, Ethiopia
}

\begin{abstract}
This study was conducted to the application of GIS and Remote Sensing for Evaluating Land use/Land Cover Dynamics in Megech Watershed, Upper Blue Nile Basin Ethiopia. Land sat images from 1986, 2001 and 2020 were used to produce three maps of the respective years using GIS with field verification. Software used for this study was Arc GIS 10.3.1 and ERDAS Imagine 14. Data from satellite images coupled with field observation and socio-economic survey revealed an effective approach for analyzing the extent, rate and spatial pattern of LU/LC change. The result showed that six land cover categories, namely forest land, wetland, woodland, farmland, bare land, water body and grassland have been identified. The general trends observed from 1986-2001 was a decrease grazing land, built up area plantation declined annually with the rate of $-0.36 \mathrm{ha} / \mathrm{year},-2.98 \mathrm{ha} / \mathrm{year}$ and -3.99 ha/year. While, natural forest, water bodies and cultivated land shows increasing trend $0.699 \mathrm{ha} / \mathrm{year}, 3.37 \mathrm{ha} / \mathrm{year}$ and $3.19 \mathrm{ha} /$ year. Similarly, between 2001-2020, natural forest, water bodies and cultivated land continued to increase with the mean annual rate of 0.4 ha.year, 1.05 ha/year and 0.03 ha respectively. Besides built up are also enhancedby $5.7 \mathrm{ha} /$ year, Whereas the reduction grazing land and plantation declined annually more or less in similar pattern with the rate of $-0.84 \mathrm{ha} /$ year and -1.64 ha/year respectively.
\end{abstract}

Keywords: Landsat, Land use, Land cover and LU/LCC.

DOI: $10.7176 / \mathrm{JRDM} / 69-04$

Publication date:October $31^{\text {st }} 2020$

\section{Introduction}

Land use/land cover (LU/LC) change is the challenging and continuous drivers of environment change (Temesgen et.al, 2017). Understanding the rate and process of change is, therefore, basic for managing the environment. Land use/ land cover (LULC) changes influence climate and weather conditions from local to global scales. They can have impacts by affecting the composition of the atmosphere and the exchange of energy between continents and the atmosphere which can lead to global warming. The negative impact of LULCC on biodiversity, climate, water, soil, and air, in particular, and on ecosystem services in general, has been recognized as one of the greatest environmental concerns for human populations today (WRI, 2001). Land use land cover has profound impacts on ecosystem services, food production and environmental balances (Huimin, 2009).According to foody (2009), Land cover change affect globally to ecological system. Moreover, ecological systems provided by forests are also sources of livelihoods for millions of people (Newsham and Bhagwat, 2016) and their disappearance affects to the life styles of especially indigenous communities.

Globally, agriculture and associated land use changes have been the principal drivers of deforestation and were responsible for $24 \%$ of global greenhouse gas (GHG) emissions in 2010 (USEPA, 2016). From 1970 to 2011, $\mathrm{CO} 2$ emissions increased by about $90 \%$, and agriculture, deforestation and other land use changes have been the second largest sources of global carbon emissions, next to the use of fossil fuels (USEPA, 2016). Agriculture accounts for $14 \%$ of GHG emissions (6.8 Gt of CO2) (GIbbs, 2007). The GHG emissions from this sector are highly likely to increase as humans struggle to increase food production by the required $70 \%$ by 2050 (GIbbs, 2007).Tropical deforestation has been responsible for $15 \%-25 \%$ of annual global GHG emissions, and accounts for nearly $70 \%$ of total GHG emissions in Africa.

Land use and land cover (LU/LC) change is a locally pervasive and globally significant ecological trend and has become an event of paramount importance to the study of global environmental change (Geist and Lambin 2001). It was the major element of global environmental changes of the past three centuries. For example, forest cover was decreased from 5000-6200 million hectares in 1700 to 4300- 5300 million hectares in 1990 (Lambin et al. 2003). In the last two decades, the area of temperate forest was increasing by almost 3 million hectares, while the tropical forest was decreasing by 12 million hectares per year (Millennium Ecosystem Assessment 2005).

Change in LULC can also affect biodiversity, contribute to forest fragmentation, leads to soil erosion, alter ecosystem services, and increase natural disasters such as flooding. This calls for global attention for continuous 
monitoring of the changes and prediction (Mengistie et al., 2013). Lambin et al. (2003) noted that land cover change information is needed regarding what changes occur, where and when they occur, the rate and the social and physical forces that drive those changes. In addition to these, Land use/ land cover change has become a central component in current strategies for managing natural resources (Zubair, 2006). Besides, land-use and land-cover changes (LUCC) increasingly have been regarded as a primary source of global environmental change such as emission of greenhouse gases, global climate change, loss of biodiversity, and loss of soil resources. However, the causes of LULC are complex and change over time and from region to region (Li, Wang, Li, \& Lei, 2016).

Furthermore, LULC change is a major issue of concern with regards to change in the global environment. The rapid growth and expansion of rapid population growth, scarcity of land, the need for more production, changing technologies are among the many drivers of LUCC in the world today (Priess, Mimler, Weber, \& Faust, 2007). Besides, LULCC is not a recent phenomenon in Ethiopia; for example, the World Resource Institute (WRI, 2001) has reported such events to have occurred during 7000-1800 BC. It is also important to notice that LULC change is one of the challenges which strongly influence the process of Agricultural development and the food security situation in Ethiopia (Daniel, 2008).

However, the current LULCC is aggravated by the scale, speed, and long-term nature of civilization (Ellis, E.2006, WRI, 2001). Moreover, much of the direct change is a consequence of land use, and today about $40 \%$ of the land surface is used for agriculture (GEF, 2012), in addition to cropland, tree plantations, urbanization in order to produce food, timber, housing, and other commodities have resulted in the reduction of many ecosystem services, including biodiversity (FAO, 2015). In order to understand the evolution of various land use systems, to analyze dramatic changes of land use/land cover at global, continental and local levels, and further to explore the extent of future changes, the current geospatial information on patterns and trends in land use/land cover are already playing an important role. Remotely sensed imageries provide an efficient means of obtaining information on temporal trends and spatial distribution of urban areas needed for understanding, modeling and projecting land changes (Elvidge, at al., 2004).

Land use dynamics is increasingly recognized as an important driver of environmental change on all spatial and temporal scales (Turner and Meyer 1994). Land use dynamics contributes significantly to earth atmosphere interactions, forest fragmentation, and biodiversity loss. That is why land use dynamics and its impacts on terrestrial ecosystems including forestry, wetland, agriculture, and biodiversity have been identified as high priority issues in global, national, and regional levels (Fu et al. 2000). LU/LC dynamics is one of the major environmental problems in megech watershed in particular and Ethiopia in general.

In relation to this, recent watershed based LULC studies showed that land cover change is brutal and there has been agricultural land size expansion at the expense of natural vegetation cover lands and marginal areas without any appropriate conservation measures (Abate 1994; Amsalu et al. 2006; Gessesse \& Kleman 2007). While, some studies conducted in the previously degraded parts of northern Ethiopia, revealed improvement of vegetation cover due to plantation and enclosure of the previously degraded hillsides in the period since the 1980s. For example, a study conducted by Woldeamlak (2002) in Chemoga watershed, East Gojjam revealed the increased of forest cover at a rate of 11 ha per annum from 1957-1998, even though it is eucalyptus plantation. Similar study by Amare (2007) and Amare et al. (2011) in Eastern Escarpment of Wello, Ethiopia and Munro et al. (2008) in Tigray highlands disclosed that vegetation cover improved since the 1980s owing to land rehabilitation efforts of the community supported by the government and multilateral donor agencies. Because of this, the study was initiated to evaluate the application of Gis and remote sensing in mapping land use land cover change patterns that is taken place connecting from the year of 1986-2020 in megech watershed Upper Blue Nile Basin.

\subsection{Objective of the study}

The aim of this study was to examine and quantify the land use land cover dynamic using Landsat imageries from the past 34 years (1986-2020) in Megech Watershed Northwest highland of Ethiopia. More specifically, this study aimed to

Analyze the temporal land use/land cover dynamics of the watershed

$>$ Map and determine the nature, extent and rate of temporal land use/land cover dynamics of the watershed

To detect and monitor land use/land cover using change detection techniques.

\section{Methods and materials}

\subsection{Study Site Description}

The Megech watershed is located in the northern part of the Lake Tana sub-basin in Amhara region of Ethiopia. It originates near the Simien Mountains at an altitude of around $4000 \mathrm{~m}$. The total watershed is $663 \mathrm{~km} 2$ at the lake inlet of which $500 \mathrm{~km} 2$ is gauged. The lake catchment lies between latitude $12^{\circ} 30^{\prime} 45^{\prime \prime}$ to $7^{\circ} 43^{\prime} 0^{\prime} \mathrm{N}$, and longitude $37^{\circ} 21^{\prime} 34^{\prime \prime} 37^{\circ} 35^{\prime} 26^{\prime \prime} \mathrm{E}$ (Afera et al., 2018). The annual rainfall ranges between $896 \mathrm{~mm}$ and $1592 \mathrm{~mm}$. The monthly maximum temperature is between $21^{\circ} \mathrm{C}$ and $27^{\circ} \mathrm{C}$, and the monthly minimum temperature is between $10^{\circ} \mathrm{C}$ and $13^{\circ} \mathrm{C}$ (F. A. Zimale et al., 2016). 
Eighty-two percent of the catchment has slopes of more than $8 \%$. Ninety-five percent of the catchment is cropland and Eutric and Leptosols cover about $82 \%$ of the area. In 2007, one-third of the volume of the reservoir was filled with sediment due to high soil erosion from the catchment (Afera et al.,2018).

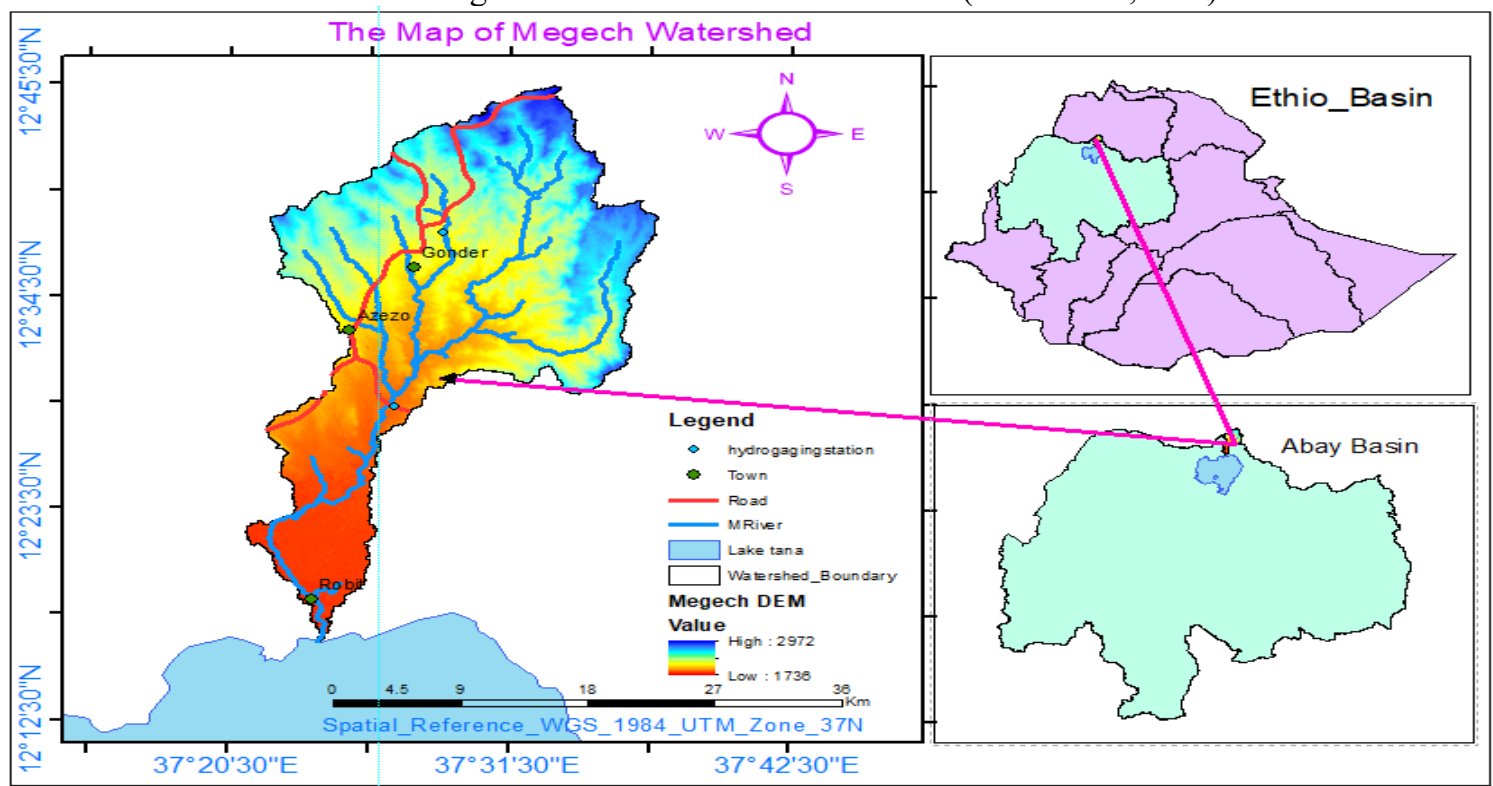

Figure: 1. Locational Map of Megech Watershed Extracted from Ethio_Gis

\subsection{Methods of data collection and procedures}

Relevant data were collected by two approaches: satellite image of 1986 to 2020 were used to detect the land use land cover changes of the study area. On the top of that secondary data were also used and collected from concerned bodies.

\section{- Satellite imageries}

Classification of land use in order to facilitate its analysis is always contentious as it collates consideration of the present land use and /or potential land use. This study, however, focused on how land is being used at present compared to the use of the same land in the past. This is due to land use changes in the watershed between 1986 and 2020 were established and described. Satellite image from Land sat TM for 1986, OLI TIRS for 2020 was obtained from Ethiopian Mapping Authority (EMA), and OLI TIRS 2020 was downloaded from USGS. It is believed that the time gap of about 34 years between the three-satellite imagery is wide enough to show changes and trends in Land Use and Land Cover dynamics in Megech Watershed. These sources of information were used to analyze land cover and land use changes over the years for the study area. Topographic maps and map of watershed weredas, both at 1:50,000 scales and associated population information were obtained from Ethiopian Mapping Authority (EMA) and Central Statistics Authority (CSA), respectively.

Digital land sat imageries of 1986, 2001 and 2020 were first radio metrically and geometrically corrected and geo-referenced to UTM geographic projection. The three imageries were patched and sub-scene clipped from the image, because of a frame covering of the study area. A Visual interpretation of the various LU/LC types on the satellite image is based on an evaluation of image characteristics such as tone, texture, size, pattern and association. Therefore, the spatial and temporal satellite imageries were acquired and analyzed for change detection and identification of land use land cover change.

- Materials used for the study

The pre-processing and post-processing of all Landsat images and generating land use/land cover change of megech watershed were done through ERDAS Imagine 2014. Microsoft Excel 2016 was used for tabulations and graphical representations. ArcGIS 10.3.1 was used to develop the study area and land use land cover map of land sat 1986, 2001 and 2020 of the study site. Besides, KML files were created and clear areal observation was done by Google earth in addition to field observation.

\subsubsection{Pre-processing approach}

\section{Atmospheric and Geometric correction}

All Landsat images used for this study were checked whether their projection was correct or not using the 2020 Landsat image as a base for the comparison. Since all Landsat images were geometrically rectified by USGS to the projection of UTM, Zone 37N, 1984 spheroid and WGS 84 Datum, there was no need of any geometric correction as they were all correct compared with 2020. In line with this, atmospheric correction was carried out for all images used for this study through ERDAS Image 2014. 


\section{Band composite preparation}

For Landsat TM and ETM+ six bands which consists of band 1-5 and band 7, were used to prepare the band composite. Similarly, six bands that consist of band 1-5 and 7 were used to generate band composite for Landsat OLI/TIRS. Accordingly, different band combination for red, blue and green were used for identifying different features of LULC during training site collection.

\section{Classification scheme}

LULC classification classes were developed based on review of other studies conducted in Ethiopia (Bewket\& Abebe, 2013; Getahun \& Van Lanen, 2015; Jacob et al., 2015) as well as United States Geological Survey Classification System (Anderson et al., 1976). Accordingly, six classes were developed with the support of Google Earth Engine that represents the LULC of the catchment (Table 2).

\section{Spectral signature collection and supervised classification}

Spectral signatures were collected randomly distributed in the catchment for respective LULC classes developed as shown in Table 2. The signature collection was supported by google earth base map to identify features precisely, which were not easily identified from band combinations. The signature collection was carried out from recent to earliest periods of Landsat image for recognizing features easily. Based on the training site sample collected from each of the Landsat images of megech watershed, LULC maps of 1986, 2001 and 2020 were produced.

A supervised classification method of maximum likelihood classifier algorithm was used for which ERADS 2014 software was applied. The supervised classification method was selected to classifying LULC classes that represent the watershed as indicated in Table 2. Maximum likelihood classifier was selected as it is confirmed by various LULC change studies for its ability in generating accurate LULC classification (Getahun\& Van Lanen, 2015; Jacob et al., 2015).

\section{Reference Data}

For the purpose of accuracy assessment, 77 coordinates collected from High resolution Google Earth engine were used for the classified image of 2020. On the other hand, for the classified images of 2001 and 1986 for each 77 coordinates were used, which are generated through stratified random sampling. This sampling method was chosen to generate proportional random points for each class.

\section{Accuracy Assessments}

The accuracy of the classified image can be checked through comparing classified pixel points with pixel points collected as a reference from fieldwork, google earth and top sheet maps (Congalton\& Green, 2008). For this project, a total of 77 reference data collected from Google earth was used for accuracy assessment for Landsat image 2020. On the other hand, for the Landsat images of 2001 and 1986 random generated points were used for accuracy assessment.

Error matrix is a commonly used method to check the accuracy of classified images with inferential and descriptive statistics. The matrix is composed of columns and row that indicate the ground truth data pixel numbers and the classified image class pixel numbers respectively (Congalton, 1991). ERDAS Imagine 2014 was used to generate overall accuracy, kappa coefficient, producer's and user's accuracy of classified image.

\subsubsection{Land Use Land Cover Change Detection Technique}

The land cover change detection was done from land cover categories derived for different periods of time (Singh, 1989).In this method, land cover map and area of each cover type was produced for the three periods. Land cover changes in the study area over 34 years of period were extracted from land sat TM of 1986 and land sat ETM imageries for 2001 and OLI_IRS 2020 respectively. The land covers maps of the three period series of images is analyzed based on land cover types area comparison and Land cover changes using tables and graphs. The changes over 34 years were analyzed and a rate of changes for each land cover type is calculated. The rate of land use land cover change was done using the following formula below (source: Barana, 2013)

$$
\mathrm{RC}=\left(\frac{\mathrm{p} 2-\mathrm{p} 1}{\mathrm{p} 1}\right) *\left(\frac{100}{\mathrm{n}}\right)=100\left(\frac{\mathrm{p} 2-\mathrm{p} 1}{\mathrm{p} 1 \mathrm{n}}\right)
$$

Where:

$\mathrm{RC}$ - rate of land use land cover changes/ha/year

$\mathrm{P} 1=$ previous year land cover

$\mathrm{P} 2=$ Current year land cover

$\mathrm{n}=$ Number of years between $\mathrm{p} 1$ and $\mathrm{p} 2$.

The land cover conversion matrix used to analyze the source and destination of each cover type and conversation comparison map prepared and each land cover change values are analyzed in excel sheet to clearly show the source and destination of cover types in table and graph of cover change dynamics. The main data used in this project included a land sat thematic mapper satellite imagery of 1986, land sat Enhanced thematic mapper satellite imagery of 2001 and OLI_TIRS 2020. A brief description of the satellite imageries used is given in table1 
Table: 1. Description of satellite imageries used in the study.

\begin{tabular}{|l|l|l|l|l|l|}
\hline Reference year & Sensor & Resolution & WRS:P/R & Date of Acquisition & Sources \\
\hline 1986 & Landsat ET & 30 & $170 / 051$ & 19011986 & USGS \\
\hline 2001 & Landsat ETM & 30 & $170 / 051$ & 12012001 & USGS \\
\hline 2020 & Landsat OLI/TIRS & 30 & $170 / 051$ & 19012020 & USGS \\
\hline
\end{tabular}

\section{Methodological framework}

In this paper a lot of activates were done. The following figure 2 shows the summary of procedural work flow.

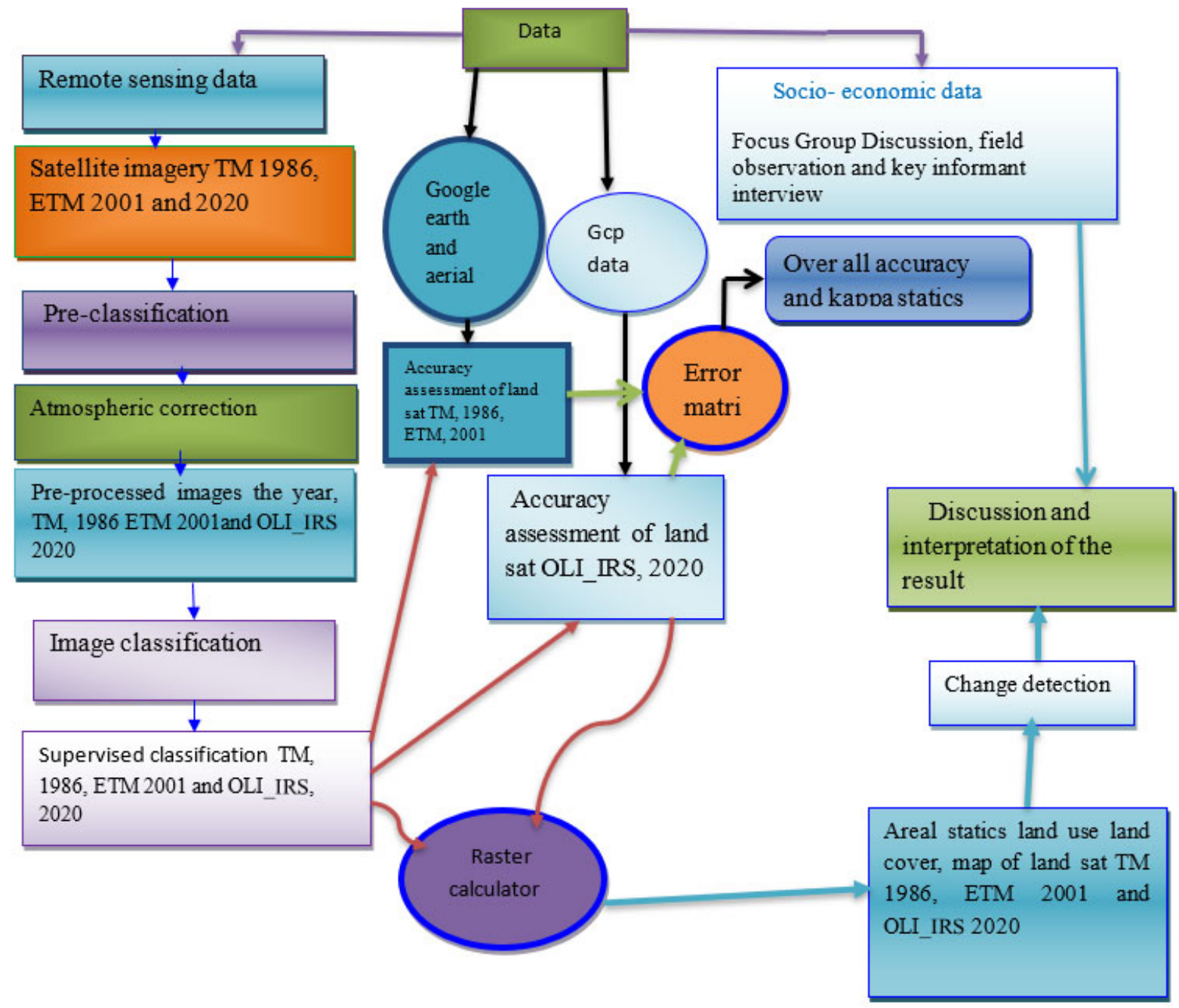

Figure.2. the Methodology flow charts for LULCC Dynamics

\section{RESULT AND DISCUSSION}

\subsection{Land Use Land Cover of 1986 - 2020}

Based on land sat imageries of the year 1986, 2001 and 2020, six major LU/LC type were identified in the study area. The major LU/LC types include forestland, grassland, cultivated land, plantation, water body and built up area (table 4.6). FAO (2004), land cover classification legends were adapted with the little modification to distinguish the cover classes in the area.

LULC classification classes were developed based on review of other studies conducted in Ethiopia (Bewket\& Abebe, 2013; Getahun \& Van Lanen, 2015; Jacob et al., 2015) as well as United States Geological Survey Classification System (Anderson et al., 1976). Accordingly, six classes were developed with the support of Google Earth Engine that represents the LULC of the catchment (Table 2). 
Table. 2: Description of LULC classification system

\begin{tabular}{|l|l|}
\hline \multicolumn{1}{|c|}{ LULC type } & \multicolumn{1}{c|}{ Description } \\
\hline Water bodies & $\begin{array}{l}\text { Area covered with water from river and streams, wetlands, ponds and swampy } \\
\text { area }\end{array}$ \\
\hline Built-up land & Settlement areas of small town and clustered rural settlement \\
\hline Forest land & Area covered with dense natural forest and shrubs forest \\
\hline Cultivated land & Area used for rain-fed and irrigation agriculture with scattered rural settlement \\
\hline Plantation & $\begin{array}{l}\text { Area used for manmade plantation which are dominated by eucalyptus and } \\
\text { related sp. }\end{array}$ \\
\hline Grazing land & $\begin{array}{l}\text { Area covered with grass and scattered shrubs and trees, which are used for } \\
\text { grazing purposes }\end{array}$ \\
\hline & \\
\hline & \\
\hline
\end{tabular}

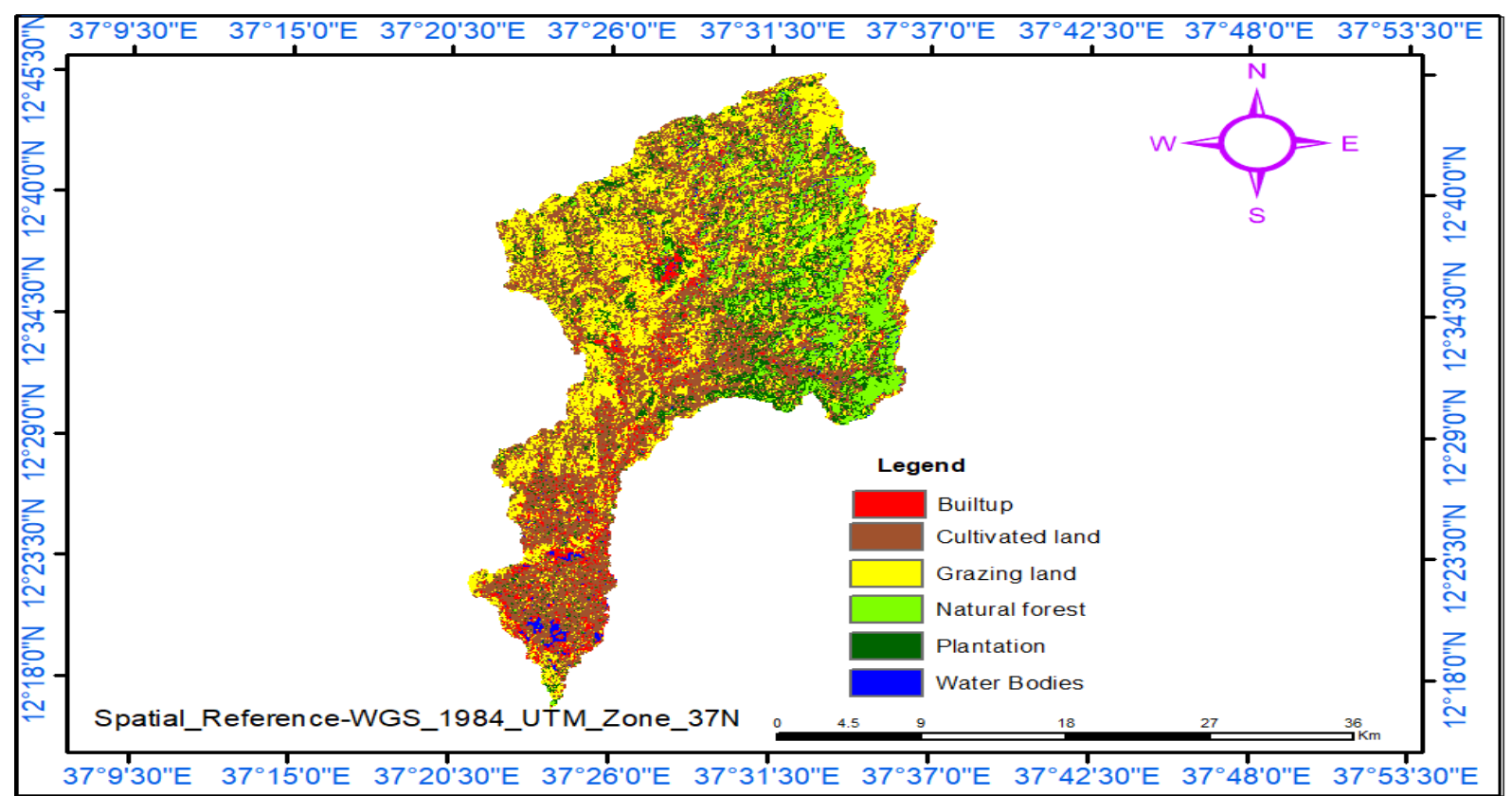

Figure 3: Land use /land cover maps of 1986 for Megech watershed

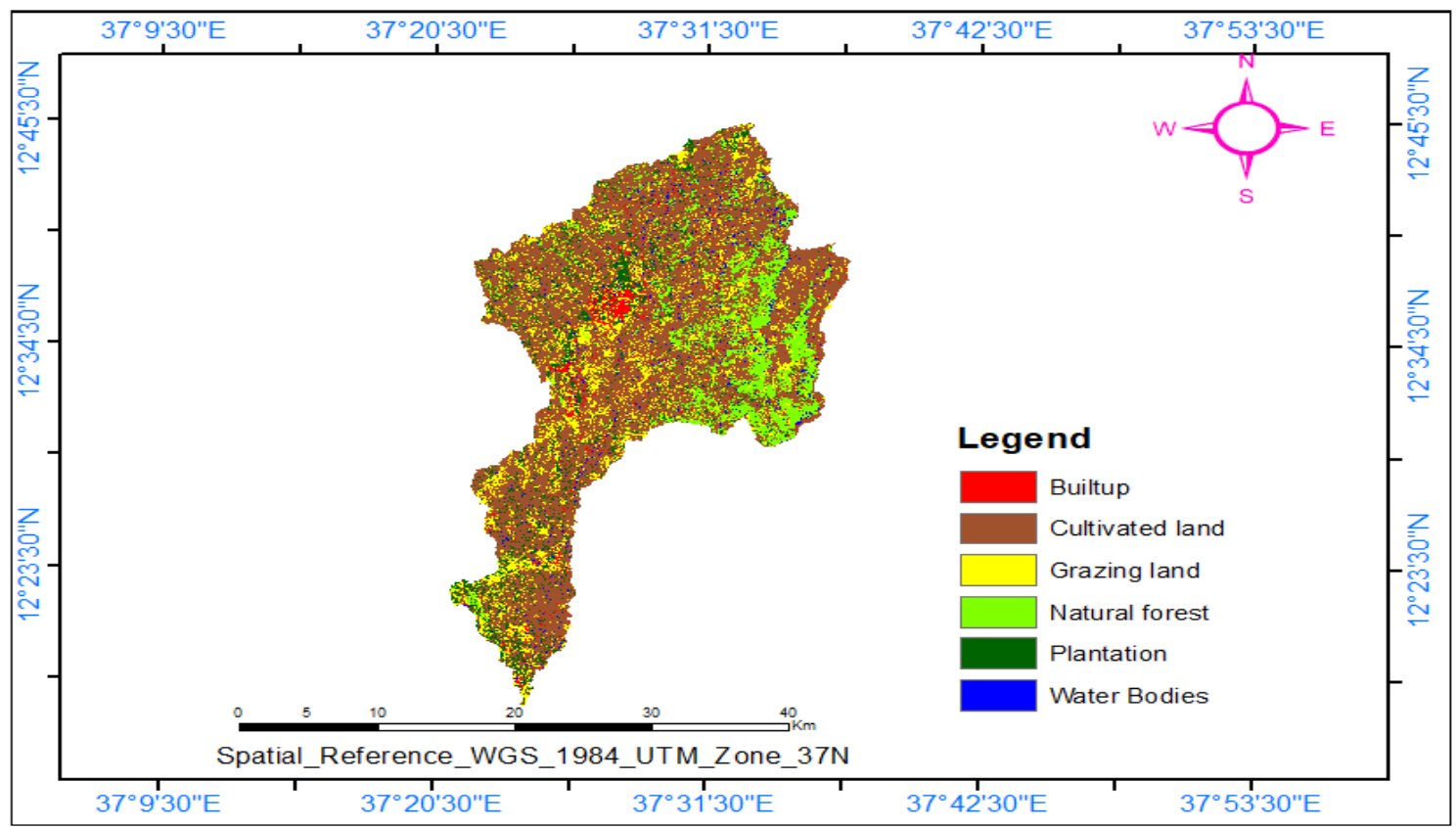

Figure 4: Land use /land cover maps of 2001 for Megech watershed 


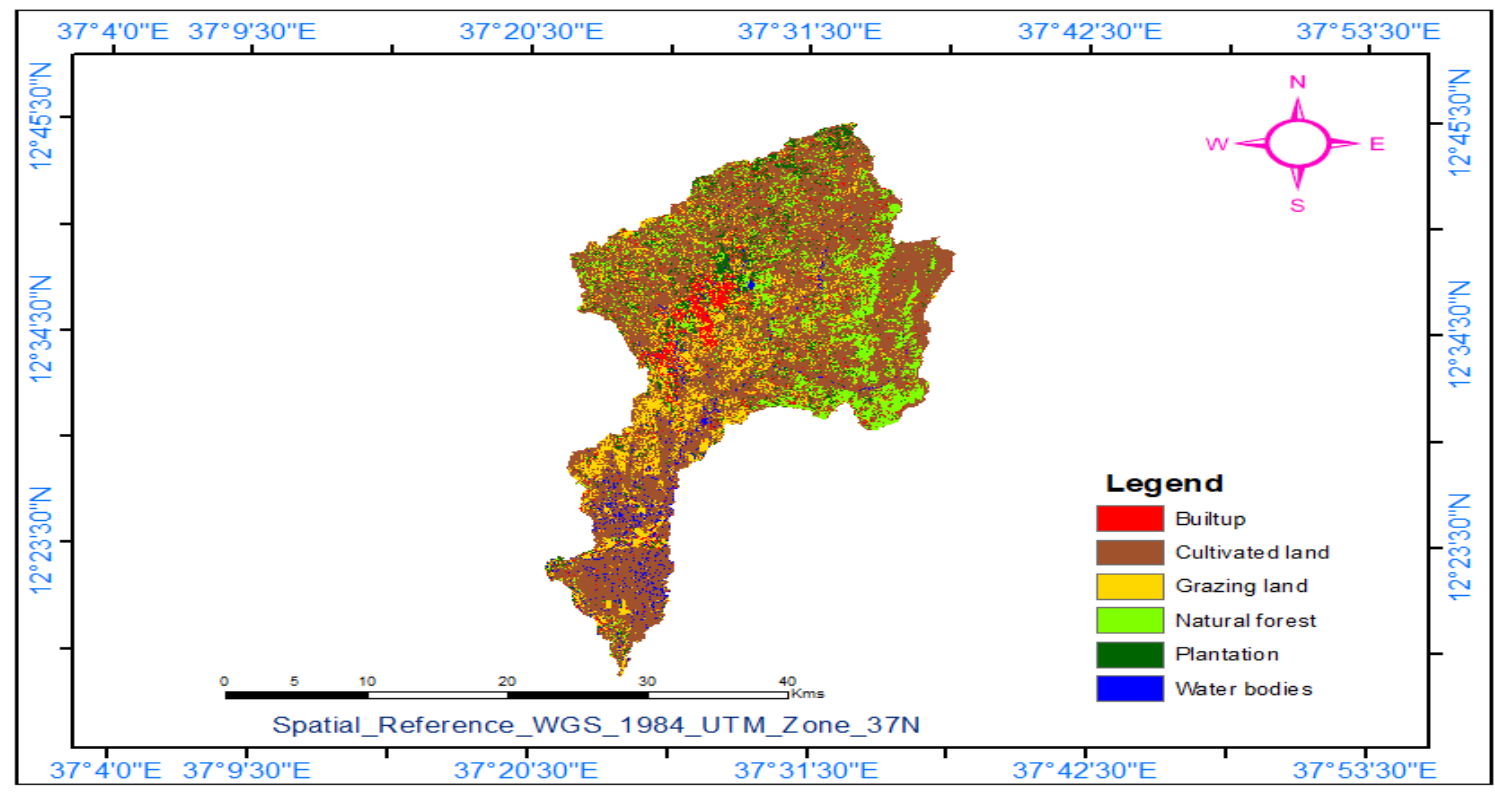

Figure 5: Land use /land cover maps of 2020 for Megech watershed

\section{LULC change analysis}

The land use and cover comparison between 1986 - 2020 showed a dynamic temporal variation. In the three periods of comparison cultivated land was dominant followed by Grazing land and natural forest (Figure 6). The extent of each land use land cover was described in detail in table.6.

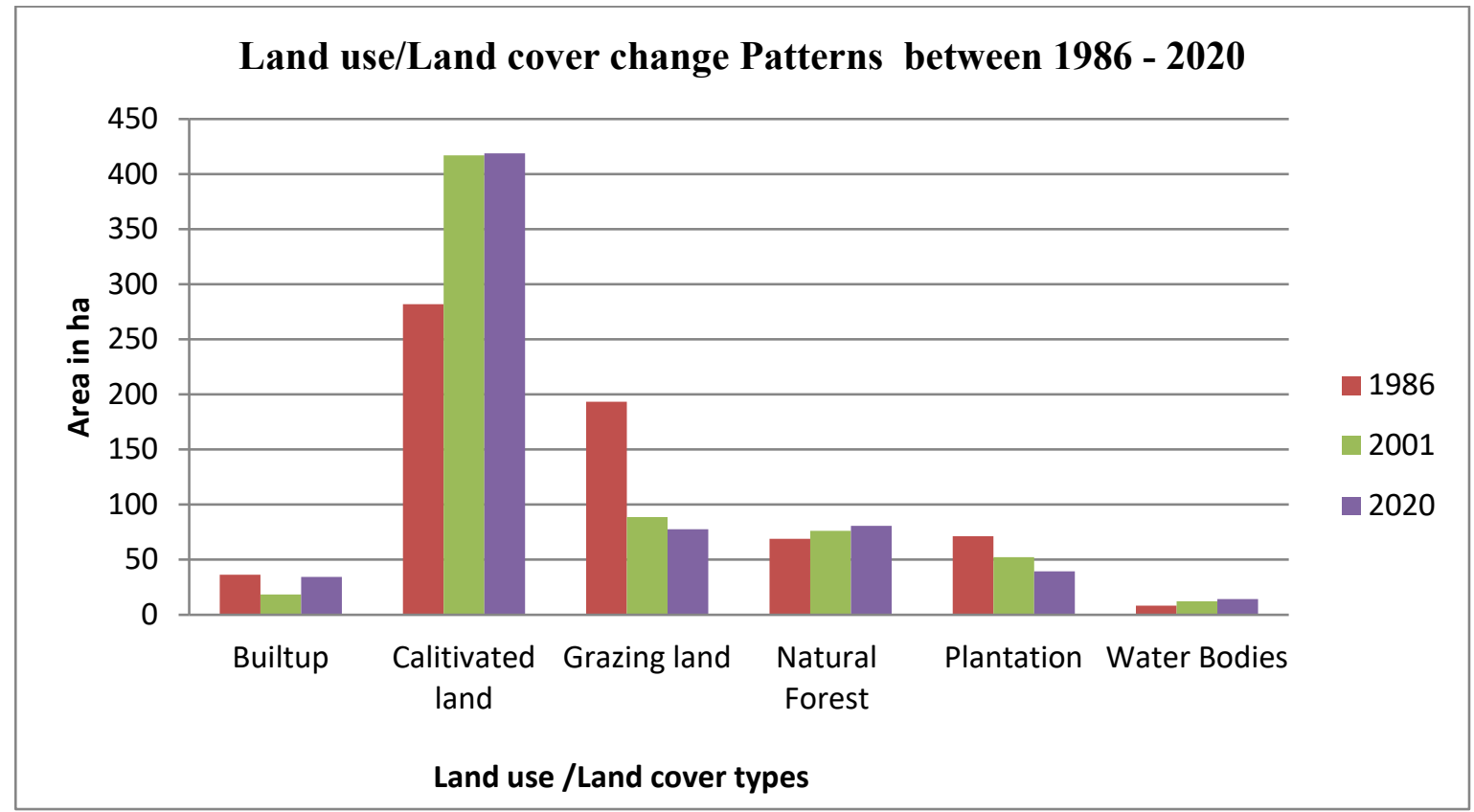

Figure 6: Land use/land cover comparison between 1986 and 2020.

\subsection{Accuracy assessment of 2020,2001 and 1986 LULC}

There are various views on the acceptable overall accuracy level. For instance, Muzein (2006) stated that the accuracy of classified images depends on its purpose by which its level of accuracy may not remain acceptable by others for specific tasks. On the other hand, $80 \%$ of the accuracy level is regarded as an acceptable and reliable result for land cover classification (Congalton \& Green, 2008). Hence, the classification result obtained for Megech catchment for three years meets the required acceptable land cover classification accuracy as their overall accuracy is greater than $80 \%$.

Kappa coefficient measures the agreement between actual agreement and agreement by chance. The measure of Kappa coefficient ranges from 0 to 1 ; where 0 denotes an agreement by a chance happening only while 1 indicates a perfect agreement among classified imagery and observed data on the ground ( Ismail \& Jusoff, 2008). 
Using the error matrix obtained from the comparison of classified pixels and reference pixels the following accuracy assessments were employed. Overall accuracy was estimated by dividing the aggregate of all correct pixels by the total number of error matrix pixels (Congalton, 1991). Consequently, for this project the overall accuracy of $80.52 \%, 81.82 \%$ and $79.22 \%$ was obtained for 2020, 2001 and 1986 respectively (Table 3 to Table 5). Table 3: Error matrix for the 2020 classified image

\begin{tabular}{|c|l|l|l|l|l|l|l|l|}
\hline \multirow{2}{*}{ Classified } & \multicolumn{9}{|c|}{ Reference data } & User's \\
\cline { 2 - 8 } & Builtup & $\begin{array}{l}\text { Cultivated } \\
\text { land }\end{array}$ & $\begin{array}{l}\text { Grazing } \\
\text { land }\end{array}$ & $\begin{array}{l}\text { Natural } \\
\text { forest }\end{array}$ & Plantation & $\begin{array}{l}\text { Water } \\
\text { bodies }\end{array}$ & Total & Accuracy (\%) \\
\hline Builtup & 10 & 1 & 0 & 0 & 0 & 1 & 12 & 83.33 \\
\hline Cultivated land & 1 & 18 & 2 & 1 & 1 & 2 & 25 & 72 \\
\hline Grazing land & 1 & 0 & 8 & 0 & 0 & 1 & 10 & 80 \\
\hline Natural forest & 0 & 0 & 0 & 8 & 2 & 0 & 10 & 80 \\
\hline Plantation & 0 & 0 & 0 & 1 & 10 & 0 & 11 & 90.91 \\
\hline Water bodies & 0 & 1 & 0 & 0 & 0 & 8 & 9 & 88.89 \\
\hline Total & 12 & 20 & 10 & 10 & 13 & 12 & 77 & $\begin{array}{c}\text { Overall } \\
\text { Accuracy } \\
=80.52\end{array}$ \\
\hline $\begin{array}{l}\text { Producer's } \\
\text { Accuracy (\%) }\end{array}$ & 83.33 & 90 & 80 & 80 & 76.92 & 66.67 & & \\
\hline
\end{tabular}

Table 4: Error matrix for the 2001 classified image

\begin{tabular}{|l|l|l|l|l|l|l|l|l|}
\hline \multirow{2}{*}{ Classified } & \multicolumn{9}{|c|}{ Reference data } & $\begin{array}{l}\text { User's } \\
\text { Accuracy } \\
\end{array}$ \\
\cline { 2 - 9 } & $\begin{array}{c}\text { Built } \\
\text { up }\end{array}$ & $\begin{array}{l}\text { Cultivated } \\
\text { land }\end{array}$ & $\begin{array}{l}\text { Grazing } \\
\text { land }\end{array}$ & $\begin{array}{l}\text { Natural } \\
\text { forest }\end{array}$ & Plantation & $\begin{array}{l}\text { Water } \\
\text { bodies }\end{array}$ & Total \\
\hline Built up & 1 & 1 & 0 & 0 & 0 & 0 & 2 & 50 \\
\hline Cultivated land & 0 & 40 & 3 & 3 & 1 & 0 & 47 & 85.11 \\
\hline Grazing land & 0 & 2 & 9 & 0 & 0 & 0 & 11 & 81.82 \\
\hline Natural forest & 1 & 1 & 0 & 7 & 0 & 0 & 9 & 77.78 \\
\hline Plantation & 0 & 0 & 0 & 1 & 5 & 0 & 6 & 83.33 \\
\hline Water bodies & 0 & 1 & 0 & 0 & 0 & 1 & 2 & 50 \\
\hline Total & 2 & 45 & 12 & 11 & 6 & 1 & 77 & Overall \\
\hline $\begin{array}{l}\text { Producer's } \\
\text { Accuracy }(\%)\end{array}$ & 50 & 88.89 & 75 & 63.64 & 83.33 & 100 & & $\begin{array}{c}\text { Accuracy } \\
=81.82\end{array}$ \\
\hline
\end{tabular}

Table 5: Error matrix for the 1986 classified image

\begin{tabular}{|c|c|c|c|c|c|c|c|c|}
\hline \multirow[t]{2}{*}{ Classified } & \multicolumn{7}{|c|}{ Reference data } & \multirow{2}{*}{$\begin{array}{l}\text { User's } \\
\text { Accuracy } \\
(\%)\end{array}$} \\
\hline & Built up & $\begin{array}{l}\text { Cultivated } \\
\text { land }\end{array}$ & $\begin{array}{l}\text { Grazing } \\
\text { land }\end{array}$ & $\begin{array}{l}\text { Natural } \\
\text { forest }\end{array}$ & Plantation & $\begin{array}{l}\text { Water } \\
\text { bodies }\end{array}$ & Total & \\
\hline Built up & 5 & 0 & 0 & 0 & 0 & 0 & 5 & 100 \\
\hline $\begin{array}{l}\text { Cultivated } \\
\text { land }\end{array}$ & 0 & 27 & 0 & 1 & 3 & 0 & 31 & 84.38 \\
\hline Grazing land & 1 & 6 & 14 & 0 & 1 & 0 & 22 & 63.64 \\
\hline $\begin{array}{l}\text { Natural } \\
\text { forest }\end{array}$ & 0 & 2 & 0 & 5 & 1 & 0 & 8 & 62.50 \\
\hline Plantation & 0 & 0 & 0 & 0 & 9 & 0 & 9 & 100 \\
\hline Water bodies & 0 & 0 & 0 & 0 & 0 & 1 & 1 & 100 \\
\hline Total & 6 & 35 & 14 & 6 & 14 & 1 & 77 & Overall \\
\hline $\begin{array}{l}\text { Producer's } \\
\text { Accuracy (\%) }\end{array}$ & 83.33 & 77.14 & 100 & 83.33 & 64.29 & 100 & & $\begin{array}{c}\text { Accuracy } \\
=79.22\end{array}$ \\
\hline
\end{tabular}

\subsection{LULC Change Detection}

The extent of LU/LC change in the study area is an important aspect of change detection. It is used to determine what is actually changing to what category of land use/cover type and to what extent (i.e. which land use class is changing to other type of LU/LC class is changing to the other LU/LC types). This information will also serve as a vital tool in planning and management decisions.

The annual rate of land conversion in Megech watershed demonstrates a periodical rate of variation between 1986 - 2020 (table5). Throughout the 1986 and 2020 grazing land, built up area (bln 1986-2020 and 1986 -2001) plantation declined annually with the rate of -0.36 ha/year,-2.98 ha/year and -3.99 ha/year. While cultivated land, 
water bodies and built-up land were increased as compared with the initial state of areal coverage with the rate of 3.23ha/year, $1.14 \mathrm{ha} /$ year and $4.95 \mathrm{ha} /$ year.

Table: 6 Land use land cover change patterns and change detection between 1986-2020

\begin{tabular}{|l|r|r|r|l|l|l|}
\hline LULC types & 1986 & 2001 & 2020 & Change Detection & $\begin{array}{c}\text { Change } \\
\text { Detection }\end{array}$ & \multicolumn{1}{c|}{$\begin{array}{c}\text { Change } \\
\text { Detection }\end{array}$} \\
\cline { 2 - 7 } & $\begin{array}{c}\text { (Area } \\
\text { ha) }\end{array}$ & (Area ha) & (Area ha ) & $\mathrm{b} / \mathrm{n} 1986-2020$ & $\mathrm{~b} / \mathrm{n} 1986-2001$ & $\mathrm{~b} / \mathrm{n} 2001-2020$ \\
\hline Built up & 3622 & 1844 & 3423 & -199 & -1778 & 1579 \\
\hline Cultivated land & 28192 & 41699 & 41870 & 13678 & 13507 & 171 \\
\hline Grazing land & 19330 & 8863 & 7749 & -11581 & -10467 & -1114 \\
\hline Natural Forest & 6885 & 7607 & 8064 & 1179 & 722 & 457 \\
\hline Plantation & 7117 & 5219 & 3934 & -3183 & -1898 & -1285 \\
\hline Water Bodies & 815 & 1227 & 1421 & 606 & 412 & 194 \\
\hline
\end{tabular}

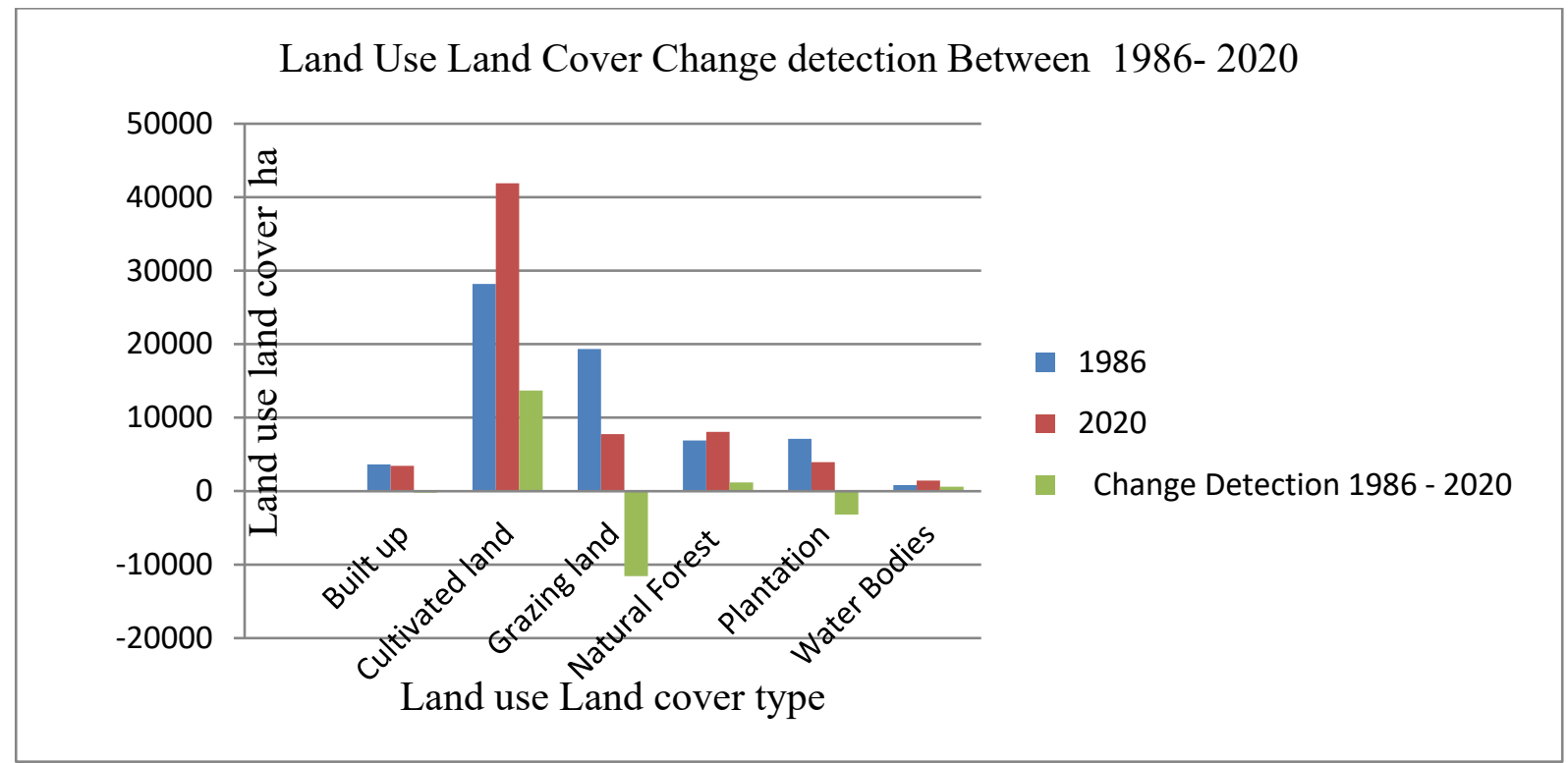

Figure: 7. Land use land cover detection between 1986-2020

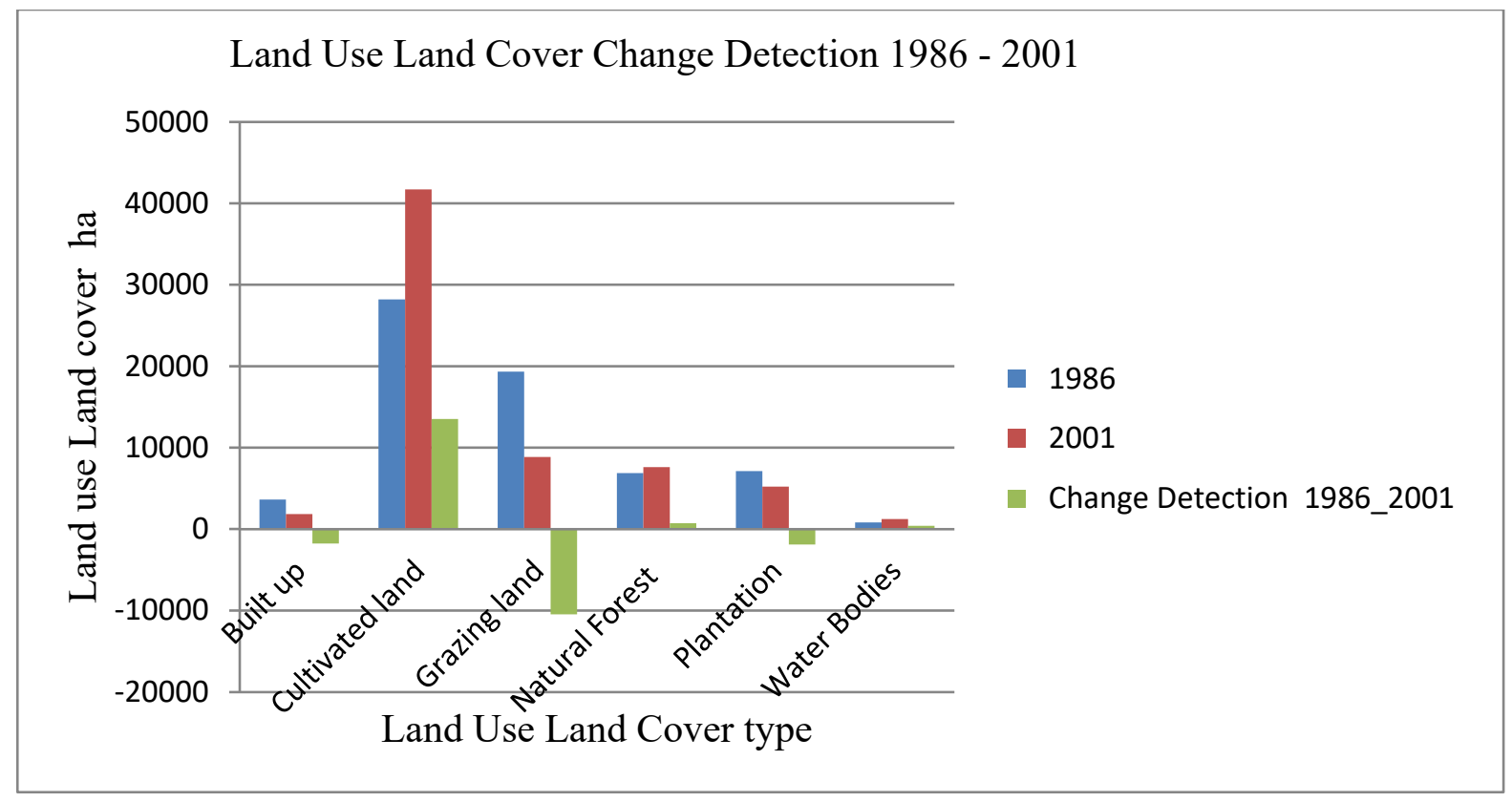

Figure: 8. Land use land cover detection between 1986-2001 


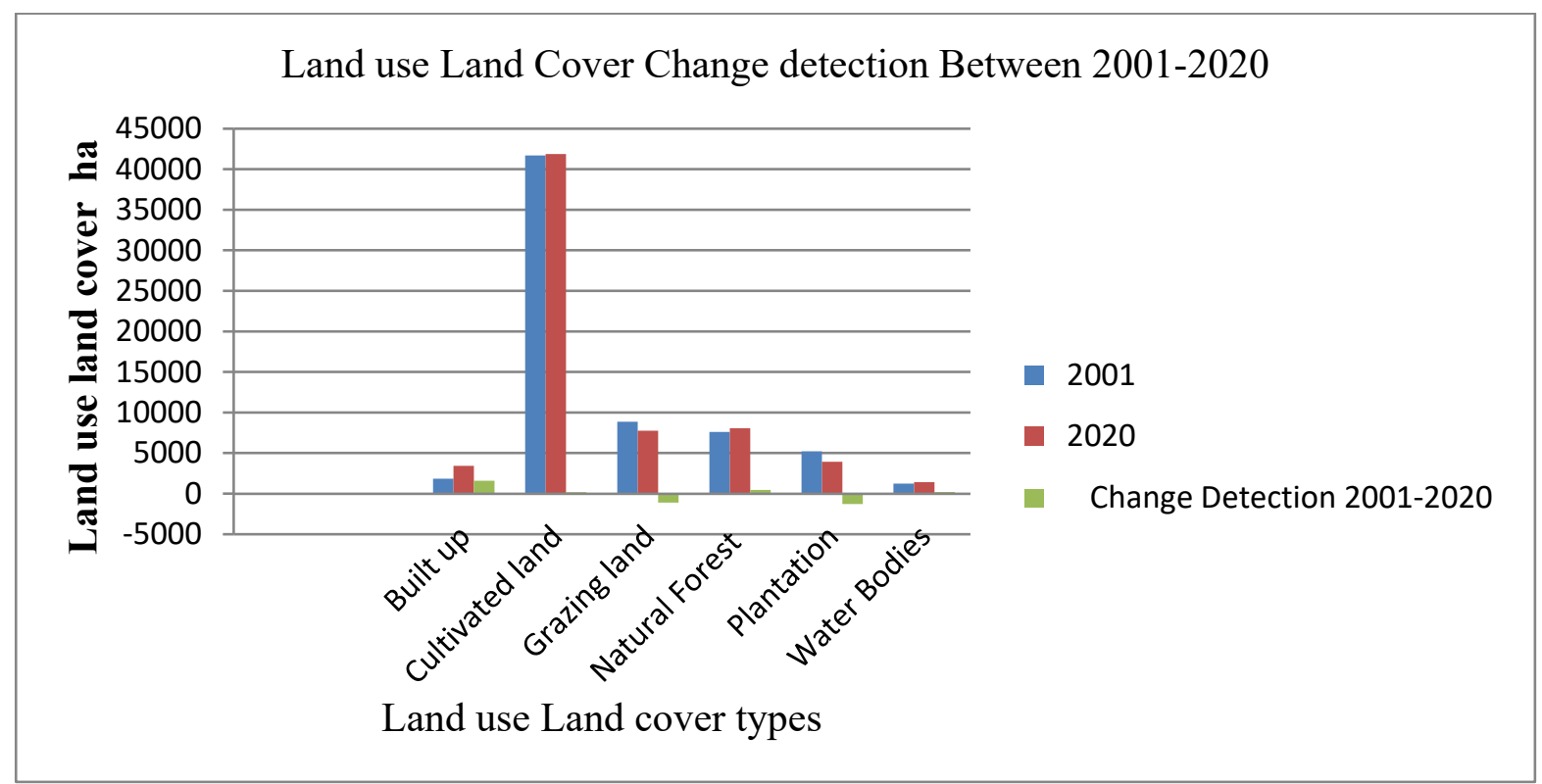

Figure: 9. Land use land cover detection between 2001-2020

Table: 8. Rate of changes in LULC between 198, 2001 and 2020

\begin{tabular}{|l|l|l|l|}
\hline \multirow{2}{*}{ Land use land cover types } & \multicolumn{2}{|c|}{ Rate of change between } \\
\cline { 2 - 4 } & $1986-2001$ & $2001-2020$ & $1986-2020$ \\
\hline Built up & -6.43 & 5.7 & -0.36 \\
\hline Cultivated land & 3.19 & 0.03 & 3.23 \\
\hline Grazing land & -3.61 & -0.84 & -3.99 \\
\hline Natural Forest & 0.699 & 0.4 & 1.14 \\
\hline Plantation & -1.78 & -1.64 & -2.98 \\
\hline Water Bodies & 3.37 & 1.05 & 4.95 \\
\hline
\end{tabular}

Table (8) showed that there was continuous reduction of grazing land and plantation with the annual rate of $3.61(1986-2001),-0.84(2001-2020)$ and -3.99 (1986-2020) in the case of grazing land. While $-1.78,-1.64$ and 2.98 happened in case of plantation in the respective years 1986-2001, 2001-2020 and 1986-2020. This was happened due to population increase and farm land expansion. Whereas, water bodies, natural forest and cultivated land showed enhancement with respective years (1986-2001, 2001-2020 and 1986-2020). Water bodies and natural forest has been increased due different types of watershed management intervention and the establishment of different dams from different of the watershed. Besides, cultivated land was enhanced due to population pressure. 
Land Use Land Cover Change Matrix between 1986 and 2020, 1986 and 2001 and 2001 and 2020(in percent)

Table.6: Land use land cover change matrix (1986 and 2020, 2001 and 1986 and 2001 and 2020

\begin{tabular}{|c|c|c|c|c|c|c|}
\hline \multicolumn{7}{|c|}{ LULC between 1986 and 2020} \\
\hline & Built up & Cultivated land & Grazing land & Natural forest & \multirow{2}{*}{$\begin{array}{l}\text { Plantation } \\
5.82\end{array}$} & Water bodies \\
\hline Builtup & 9.93 & 4.32 & 5.42 & 5.99 & & 8.07 \\
\hline \multicolumn{2}{|l|}{ Cultivated land } & 71.08 & 61.44 & 31.75 & 53.06 & 53.28 \\
\hline Grazing land & 14.84 & 10.6 & 19.49 & 1.57 & 6.06 & 14.56 \\
\hline Natural forest & 2.87 & 4.88 & 4.74 & 54.39 & 23.54 & 15.18 \\
\hline Plantation & 3.21 & 5.27 & 6.86 & 5.75 & 9.89 & 4.68 \\
\hline Water bodies & 7.19 & 3.19 & 1.21 & 0.34 & 1.21 & 3.91 \\
\hline \multicolumn{7}{|c|}{ LULC between 1986 and 2001} \\
\hline & Builtup & Cultivated land & Grazing land & Natural forest & Plantation & Water bodies \\
\hline Builtup & 10.12 & 2.62 & 2.6 & 2.26 & 2.29 & 5.76 \\
\hline Cultivated land & 61.36 & 73.75 & 60.1 & 26.32 & 46.64 & 51.11 \\
\hline Grazing land & 14.23 & 10.97 & 23.42 & 2.56 & 10.46 & 15.98 \\
\hline Natural forest & 2.21 & 2.96 & 3.17 & 57.66 & 25.08 & 11.51 \\
\hline Plantation & 8.16 & 7.5 & 9.2 & 3.97 & 13.46 & 7.35 \\
\hline Water bodies & 3.31 & 1.53 & 0.67 & 7.03 & 1.64 & 7.97 \\
\hline & & LULC bet & veen 2001 and & 020 & & \\
\hline & Builtup & Cultivated land & Grazing land & Natural forest & Plantation & Water bodies \\
\hline Builtup & 25.72 & 3.75 & 8.02 & 4.38 & 5.39 & 12.29 \\
\hline Cultivated land & 43.17 & 75.36 & 47.55 & 24.75 & 48.24 & 39.68 \\
\hline Grazing land & 15.21 & 10.25 & 32.54 & 1.46 & 6.74 & 4.5 \\
\hline Natural forest & 7.35 & 4.48 & 4.93 & 60.19 & 12.95 & 30.04 \\
\hline Plantation & 3.24 & 3.77 & 4.96 & 9.03 & 23.68 & 5.48 \\
\hline Water bodies & 5.32 & 2.4 & 2.01 & 0.2 & 3.01 & 8.01 \\
\hline
\end{tabular}

\section{Conclusion}

This study was conducted to the application of GIS and Remote Sensing for Evaluating Land use/Land Cover Dynamics in Megech Watershed, Upper Blue Nile Basin Ethiopia. Land sat images from 1986, 2001 and 2020 were used to produce three maps of the respective years using GIS and remote sensing with field verification. Data from satellite images coupled with field observation and socio-economic survey revealed an effective approach for analyzing the extent, rate and spatial pattern of LU/LC change.

The result showed that six land cover categories, namely forest land, wetland, woodland, farmland, bare land, water body and grassland have been identified. The general trends observed from 1986-2001 was a decrease grazing land, built up area and plantation declined annually with the rate of $-0.36 \mathrm{ha} /$ year,-2.98 ha/year and -3.99 ha/year. While, natural forest, water bodies and cultivated land shows increasing trend 0.699ha/year,3.37 ha/year and 3.19 ha/year. Similarly, between 2001-2020, natural forest, water bodies and cultivated land continued to increase with the mean annual rate of 0.4 ha.year, 1.05 ha/year and 0.03 ha respectively. Besides built up are also enhanced by $5.7 \mathrm{ha} /$ year, Whereas the reduction grazing land and plantation declined annually more or less in similar pattern with the rate of $-0.84 \mathrm{ha} /$ year and -1.64 ha/year respectively.

From this paper result we concluded that RS is crucial for understanding land use/land cover dynamics. ERDAS imagine 2014 that integrates google earth engine makes easy to identify features for the current land cover features. The land cover analysis reveals that Megech watershed showed a dynamic in different land use classes between 1986 and 2020. Specifically, cultivated land, forest, built-up and water bodies increased, while grazing land showed a decreasing trend.

\section{Acknowledgement}

This research work was accomplished by the efforts of many individuals, administration office and institutions. Besides, the authors greatly acknowledged farmers and agricultural development agents of watershed wereda for their interest for providing necessary information.

\section{Reference}

Abate S (2011). Evaluating the land use and land cover dynamics in Borena Woreda of South Wollo highlands, Ethiopia. Journal of Sustainable Development in Africa. 13 (1): 87-05.

Amare B (2007). Landscape Transformation and Opportunities for Sustainabable Land Managewment Along the Escarpmemts of Wello, Ethiopia. PhD Thesis, Bern University, Bern.

Amare B, Hurni H and Gete Z (2011). Responses of rural households to the impacts of population and land-use 
changes along the Eastern Escarpment of Wello, Ethiopia. Norwegian Journal of Geography. 65:42-53.

Amsalu A, Leo S and Jan de G (2006). Long-term dynamics in land resource use and the driving forces in Beressa watershed, highlands of Ethiopia. Journal of Environmental management. 83: 13-32.

Anderson, J. R.,Hardy, E. E.,Roach, J. T.\& Witmer, R. E. (1976). A land use and land cover classification system for use with remote sensor data (Vol. 964): US Government Printing Office.

Belay T (2002). Land-cover/land-use changes in the Derekolli catchment of the South Welo Zone of Amhara Region, Ethiopia. Michigan State University Press. 18(1): 1-20.

Bewket, W.\& Abebe, S. (2013). Land-use and land-cover change and its environmental implications in a tropical highland watershed, ethiopia. International Journal of Environmental Studies, 70(1), 126-139. doi:10.1080/00207233.2012.755765

Congalton, R. G. (1991). A review of assessing the accuracy of classifications of remotely sensed data. Remote Sensing of Environment, 37(1), 35-46.

Congalton, R. G.\& Green, K. (2008). Assessing the accuracy of remotely sensed data: Principles and practices: CRC press.

Daniel Ayalew.(2008). Remote sensing and gis-based Land use and land cover change detection in the upper Dijo river catchment, Silte zone, southern Ethiopia; Working papers on population and land use change in central Ethiopia, nr. 17.

Elvidge, C. D., Sutton, P. C., Wagner, T. W., et al. (2004).Urbanization. In: G.Gutman, A. Janetos, Justice C., et al (Eds.), Land change science: Observing, monitoring, and understanding trajectories of change on the earth's surface (pp.315-328). Dordrecht, Netherlands: Kluwer Academic publishers.

Foody,G.(2002).Status of land cover classification, accuracy assessment, remote sensing of environment, 80(1), 185-201.

Getahun, Y. S.\& Van Lanen, H. (2015). Assessing the impacts of land use-cover change on hydrology of melka kuntrie subbasin in ethiopia, using a conceptual hydrological model. Hydrology: Current Research, 2015.

Girmay K (2003). GIS Based Analysis of Land Use /Land Cover, Land Degradation and Population Changes: A Study of Boru Metero Area of South Wello, Amhara Region. MSc thesis, AAU, pp1-120

Huimin.L(2009) Assessing the consequence of land use change on agricultural productivity in china,Elsevier,1319.

Ismail, M. H.\& Jusoff, K. (2008). Satellite data classification accuracy assessment based from reference dataset. International Journal of Computer and Information Science and Engineering, 2(2), 96-102.

Judith MS (2013). Land use and land cover changes and their implications for human-wildlife conflicts in the semi-arid rangelands of southern Kenya. Journal of Geography and regional planning. 6(5):193-199

Jacob, M.,Romeyns, L.,Frankl, A.,Asfaha, T.,Beeckman, H.\& Nyssen, J. (2015). Land use and cover dynamics since 1964 in the afro-alpine vegetation belt: Lib amba mountain in north ethiopia. Land Degradation \& Development.

Lambin E, Geist H and Lepers E (2003). Dynamics of land use and land cover change in tropical regions. Annu. Rev. Environ. Resour. 28: 206-232

Lambin, E. F. and Geist, H. J. (2003). Dynamics of Land Use and Land Cover Change In Tropical Regions. Annual Reviews Environ. Resource 28: 205-241.

Lambin, E.F., Turnerb, B.L., Geista, H.J., et al. (2001). The Causes of Land-Use and Land-Cover Change: Moving Beyond the Myths. Global Environmental Change 11: 261-269.

Messay M (2011). Land-use/land-cover dynamics in Nonno district, Central Ethiopia. Journal of Sustainable Development in Africa. 13(1): 123-139.

Millennium Ecosystem Assessment (2005). Ecosystems and Human Well-being: Synthesis. Island Press, Washington, DC.

Munro R, Deckers J, Mitiku H, Grove A, Poesen J and Nyssen J (2008). Soil landscapes, land cover change and erosion features of the Central Plateau region of Tigrai, Ethiopia: Photo-monitoring with an interval of 30 years. Catena. 75: 55-64.

Muzein, B. S. (2006). Remote sensing \& gis for land cover/land use change detection and analysis in the seminatural ecosystems and agriculture landscapes of the central ethiopian rift valley. University of Dresden Professor Dr. Michael Köhl: Institute for World Forestry, University of Hamburg.

Temesgen Gashaw*, Tafa Tulu, Mekuria Argaw and Abeyou W. Worqlul. (2017). Evaluation and prediction of land use/ land cover changes in the Andassa watershed, Blue Nile Basin, Ethiopia.

ZHANG D.-S., X.-Y. L., Y.-J. M., H.-Y. X., AND. WANG J.-H. (2009). Impact of Land Use and Land Cover Change on Environmental Degradation in Lake Qinghai Watershed, Northeast Qinghai-Tibet Plateau. Land degradation \& development Land Degrad. 